\title{
AGGREGATIBACTER ACTINOMYCETEMCOMITANS AND PREVOTELLA INTERMEDIA IN ADVANCED CHRONIC PERIODONTITIS PATIENTS
}

R.D. Vaithilingam, T.B. Taiyeb-Ali, R. Yusuf. Aggregatibacter actinomycetemcomitans and Prevotella intermedia in advanced chronic periodontitis patients. Annal Dent Univ Malaya 2010; 17: 1-8.

\section{ABSTRACT}

This cross-sectional study was carried out to identify A. actinomycetemcomitans and $P$. intermedia in the subgingival plaque of three ethnic groups (Malays, Chinese and Indians) in a selected group of adult Malaysians with advanced Chronic Periodontitis and to correlate these findings with their periodontal status. Thirty periodontally diseased adults were age, gender and ethnically matched with 30 healthy individuals. Clinical parameters were assessed for all. Subgingival plaque samples were collected for identification of $A$. actinomycetemcomitans and $P$. intermedia using polymerase chain reaction. Prevalence for $P$. intermedia $(83.3 \%)$ was high and A. actinomycetemcomitans $(6.7 \%)$ low in the total subject population. $P$. intermedia and $A$. actinomycetemcomitans were more prevalent in diseased $(86.7 \%, 10 \%$ respectively) than in healthy $(80 \%, 3.33 \%$ respectively) subjects. $A$. actinomycetemcomitans was detected in $15 \%$ Indians, 5\% Malays but none of the Chinese subjects whereas P. intermedia was detected in $90 \%$ Malays, $85 \%$ Indians and $75 \%$ Chinese subjects. No significant association between presence of A. actinomycetemcomitans and $P$. intermedia with race and periodontal disease status was found. Only $A$. actinomycetemcomitans had a significant association with clinical attachment level (CAL) $(p<0.05)$. In conclusion, in this small subject group, none of the pathogens were associated with race and periodontal disease status and only A. actinomycetemcomitans had a significant association with CAL.

Key words: Aggregatibacter actinomycetemcomitans; chronic periodontitis; ethnicity; periodontopathogens; Prevotella intermedia

\section{INTRODUCTION}

Periodontitis is a multi-factorial disease with the dental biofilm as its essential component. Between 700 different types of bacteria have been detected in the mouth $(1,2)$ out of which 400 or more species reside in the subgingival biofilm area (3). Most of these bacteria are thought to be an indigenous part of the normal oral flora and not associated with oral diseases. However, Aggregatibacter actinomycetemcomitans (A. Actinomycetemcomitans), Prevotella intermedia ( $P$.
Original Article

R.D. Vaithilingam ${ }^{1}$, T.B. Taiyeb-Ali', R. Yusuf ${ }^{2}$
'Department of Oral Pathology,
Oral Medicine and Periodontology,
Faculty of Dentistry, University of Malaya,
Malaysia
'Department of Molecular Medicine,
Faculty of Medicine, University of Malaya,
Malaysia
Corresponding author: Dr. Rathna Devi Vaithilingam

intermedia), Porphyromonas gingivalis (P. Gingivalis), Tannarella forsythensis (T. forsythensis) (formerly known as Bacteroides forsythus), Campylobacter rectus, Eikenella corrodens, Fusobacterium nucleatum and some uncultivable spirochaetes have been implicated as major putative pathogens associated with the development and progression of periodontitis (4).

A susceptible host and/ or local environmental conditions that increase susceptibility in addition to the pathogenic bacteria may be required before disease progression occurs (5). Ethnicity, an important variable in the pathogenesis of periodontal disease, also has an influence on the presence and levels of certain bacteria in the subgingival microbiota (6). Differing prevalences of the various putative pathogens like $A$. actinomycetemcomitans, $P$. intermedia, $P$. gingivalis, $T$. forsythensis and other periodontopathogens have been reported from different parts of the world (7-10) suggesting that there may be specific distribution patterns in ethnically distinct populations. The Malaysian population, made up of 3 major ethnic groups which are the Malays, Chinese and Indians, presents with differences in the extent and severity of periodontal destruction possibly associated with different risk factors. Epidemiological investigations carried out in Malaysia showed that ethnicity may be an important risk factor as the Indian subjects have a higher prevalence of marked periodontal destruction as indicated by deep periodontal pocketing (11).

The presence of $A$. actinomycetemcomitans and $P$. intermedia have been established in advanced Chronic Periodontitis, but thus far, no known studies have been done in implicating its presence with ethnicity and clinical periodontal status in the Malaysian population. The objectives of this study are a) to identify the presence of A. actinomycetemcomitans and $P$. intermedia in the subgingival plaque of the three ethnic groups of selected adult Malaysians with Advanced Chronic Periodontitis and b) to correlate the 
microbiological profile of the subjects in relation to A. actinomycetemcomitans and $P$. intermedia with their clinical periodontal status.

\section{MATERIALS AND METHODS}

\section{Clinical examination of patient groups}

\section{Sample groups}

This study is a cross-sectional study using a convenient sample of 60 adult subjects made up of 30 periodontally diseased patients (referred to the Periodontal Unit, Faculty of Dentistry, University of Malaya from its Primary Dental Care Unit) and 30 healthy subjects (patients from the Primary Dental Care Unit as well as the staff of the Faculty of Dentistry, University of Malaya). In each test and control group, there were 10 Malays, 10 Chinese and 10 Indians. The test and control groups were matched in age (within a range of \pm 5 years), sex and ethnicity. Patients were within the age range of $35-65$ years. For the test group, patients with advanced Chronic Periodontitis were chosen with probing pocket depths of $6 \mathrm{~mm}$ or more and clinical loss of attachment of $5 \mathrm{~mm}$ or more at 4 or more teeth. For the control group, patients with a healthy periodontium were chosen with no clinical attachment loss greater than $3 \mathrm{~mm}$. Patients with known systemic disease and patients who had been on antibiotic cover or who have had periodontal therapy within the past 6 months were excluded from the study. Ethical Clearance had been obtained for this study (Ethical Clearance No: DFPE 0301/0003[P]) from the Ethics Committee, University of Malaya. The nature of the study was explained and written consent was obtained from each patient.

\section{Clinical parameters and measurements}

Clinical parameters of the patients that were assessed were Plaque index (12), Gingival index (13), Bleeding index (14), probing pocket depth (PPD) and clinical attachment level (CAL). All measurements for PPD and CAL were recorded to the nearest millimeter with a Williams periodontal probe. The teeth selected were all canines, first or second incisors, first or second premolars and the first or second molars in each quadrant. For the incisors, premolars and molars, teeth with the higher probing pocket depths were chosen. The number of teeth present was also recorded. Clinical measurements were performed by two examiners (author included), and prior to this study a reproducibility study was done to validate intra and inter examiner reproducibility.

\section{Sampling of plaque}

Subgingival plaque samples were obtained by first isolating the sites to be sampled with cotton rolls and supragingival plaque was then removed with cotton pellets, before sampling of subgingival plaque was done with sterile curettes. In test subjects, sampling was done at 4 or more teeth with the deepest probing depths $(\geq 6 \mathrm{~mm})$ which showed bleeding on probing and these plaque samples were pooled. In control patients, sampling was done at interproximal sites that did not show any bleeding on probing. Subgingival scrapings were collected from the base of pockets up to the gingival margin. Scrapings were then resuspended in $1.5 \mathrm{ml}$ of phosphate buffered saline and stored at $-80^{\circ}$ $\mathrm{C}$ until polymerase chain reaction (PCR) procedure was commenced.

\section{PCR identification of bacterial strains}

Bacterial strains and DNA template

Bacterial strains used as positive controls were ATCC (American Type Cell Culture) 43718 for $A$. actinomycetemcomitans and ATCC 25611 for $P$. intermedia which were obtained from Microbiology Department, King's College, London. The strains were suspended in Brain Heart Infusion (BHI) media. The DNA extraction was done as follows: $100 \mu \mathrm{l}$ of bacterial sample was incubated for 10 minutes at $95^{\circ} \mathrm{C}$. It was then cooled in ice for 5 minutes and centrifuged at $14,500 \times \mathrm{g}$ (maximum speed on the Eppendorf Mini spin plus microcentrifuge machine) for 2 minutes to obtain the DNA supernatant. The DNA was then stored at $-80^{\circ} \mathrm{C}$ until used (15).

\section{PCR amplification}

The oligonucleotide primers targeting the leukotoxin gene ltx A of the leukotoxin operon (16) were used to detect $A$. actinomycetemcomitans. The primers used to detect $P$. intermedia were derived from the $16 \mathrm{~S}$ rRNA sequences of $P$. intermedia sensu strict (15) and were able to distinguish $P$. intermedia from Prevotella nigrescens.

The protocol used for $A$. actinomycetemcomitans (17) and P. intermedia were as shown in Table 1. For both $A$. actinomycetemcomitans and $P$. intermedia, PCR was carried out at $94^{\circ} \mathrm{C}$ for 3 minutes for 1 cycle, followed by 35 subsequent cycles of denaturation at $94^{\circ} \mathrm{C}$ for 1 minute, annealing at $60^{\circ} \mathrm{C}$ for 1 minute $\left(58^{\circ} \mathrm{C}\right.$ for 40 seconds for $P$. intermedia) and extension at $72^{\circ} \mathrm{C}$ for 1 minute $\left(72^{\circ} \mathrm{C}\right.$ for 2 minute for $P$. intermedia). The final extension was carried out at $72^{\circ} \mathrm{C}$ for 10 minutes.

The PCR products were then visualized by illumination of the agarose gel with ultraviolet light and viewed under a transilluminator (Bio Rad, USA). The bands for the positive control for $A$. actinomycetemcomitans were at $285 \mathrm{bp}$ and for $P$. intermedia were at $267 \mathrm{bp}$.

\section{Statistical analysis}

Fisher's Exact test was used to obtain the significance level of association between presence of A. actinomycetemcomitans and P. intermedia and groups (diseased and healthy) as well as ethnicity. Cross tabulation was done to assess detection frequency of single and mixed bacterial infections in 
Table 1. List of reagents used for PCR protocol

\begin{tabular}{lcc}
\hline Reagents & A. actinomycetemcomitans & P. intermedia \\
\hline $\begin{array}{l}\text { Bacterial } \\
\text { suspension }\end{array}$ & $10 \mu \mathrm{l}$ & $10 \mu \mathrm{l}$ \\
$\begin{array}{l}\text { Forward primer } \\
\text { (Qiagen Operon) }\end{array}$ & $100 \mathrm{pmol}$ & $100 \mathrm{pmol}$ \\
$\begin{array}{l}\text { Reverse primer } \\
\text { (Qiagen Operon) }\end{array}$ & $100 \mathrm{pmol}$ & $100 \mathrm{pmol}$ \\
$\begin{array}{l}\text { dNTPs } \\
\text { (Finnzymes Oy) }\end{array}$ & $200 \mu \mathrm{M}$ & \\
$\begin{array}{l}\text { Thermophilic DNA } \\
\text { polymerase 10x } \\
\text { buffer } \\
\text { (Promega, USA) }\end{array}$ & $5 \mu \mathrm{l}$ & \\
$\begin{array}{l}\text { Magnesium } \\
\text { Chloride }\end{array}$ & & \\
$\begin{array}{l}\text { Taq DNA } \\
\text { Polymerase } \\
\text { (Promega, USA) }\end{array}$ & $2 \mathrm{mM}$ & $2 \mathrm{mM}$ \\
\hline
\end{tabular}

subjects harbouring the pathogens. One way ANOVA was utilised to compare mean clinical scores with presence or absence of $A$. actinomycetemcomitans and $P$. intermedia in both the diseased and healthy groups. Since A. actinomycetemcomitans positive cases were low, ANOVA testing for mean CAL score was repeated using Mann-Whitney test. The statistical analysis for the study was done using the SPSS 11.5 for Windows.

\section{RESULTS}

A total of 60 patients, 30 males $(50 \%)$ and 30 females $(50 \%)$ were examined. Sociodemographic data of subjects is shown in Table 2. The mean age was $46.08 \pm$ 8.11 years. Out of the 60 subjects, $16.7 \%$ were smokers.
In the diseased group, $23.3 \%$ were smokers while only $10 \%$ were smokers in the healthy group. In view of the difficulty in recruiting these matched subjects, smokers were not excluded, which may have been a potential cause of confounding bias. No significant difference was found between the clinical parameters of the diseased subjects in the three ethnic groups (Table 3 ).

As shown in Table 4, the prevalence level for A. actinomycetemcomitans in the total subject population was low $(6.67 \%)$. In the diseased group the prevalence of $A$. actinomycetemcomitans was $10 \%$ whereas in the healthy group the prevalence of $A$. actinomycetemcomitans was $3.33 \%$. The prevalence for A. actinomycetemcomitans in the total Indian subjects was the highest followed by total Malay subjects. $A$. actinomycetemcomitans was not detected in any of the Chinese subjects.

Table 4 also shows that the presence of $P$. intermedia in the total population as well as diseased and healthy groups were high. In the Indian and Chinese groups, $P$. intermedia was found to be slightly higher in the diseased groups as compared to the healthy population. However in the Malay group, $P$. intermedia was found equally in both diseased and healthy groups.

Race comparisons among the three ethnic groups showed there was no association between the presence of A. actinomycetemcomitans and $P$. intermedia and ethnicity. The odds ratio of detecting $A$. actinomycetemcomitans bacteria in diseased as compared to healthy was 3.22 (95\% $\mathrm{CI}=0.32,32.89)$. The odds ratio of detecting $P$. intermedia bacteria in diseased as compared to healthy was $1.63(95 \%$ $\mathrm{CI}=0.41,6.47)$.

Analysis of detection frequency of single and mixed bacterial infections showed that of the total 60 subjects, $54(90 \%)$ subjects were found to harbour at least one of the two pathogens. Of these infected

Table 2. Socio-demographic characteristics of study subjects (Chi-square for income level and Fisher's Exact Test for gender, smoking habits and regularity of dental visits)

\begin{tabular}{|c|c|c|c|c|}
\hline Characteristics & Diseased & Healthy & Total & $p$-value \\
\hline \multicolumn{5}{|l|}{ Age } \\
\hline Mean (sd) & $46.53(8.68)$ & $45.63(7.62)$ & $46.08(8.11)$ & 0.67 \\
\hline \multicolumn{5}{|l|}{ Gender } \\
\hline Male $\mathrm{n}(\%)$ & $15(50)$ & $15(50)$ & $30(100)$ & 0.6 \\
\hline Female $\mathrm{n}(\%)$ & $15(50)$ & $15(50)$ & $30(100)$ & \\
\hline \multicolumn{5}{|l|}{ Income level } \\
\hline Low n(\%) & $14(46.7)$ & $6(20)$ & 20(33.3) & \\
\hline Middle n(\%) & $14(46.7)$ & $16(53.30)$ & $30(50)$ & 0.03 \\
\hline High $n(\%)$ & $2(6.6)$ & $8(26.7)$ & $10(16.7)$ & \\
\hline \multicolumn{5}{|l|}{ Smoking habits } \\
\hline Smoker n(\%) & $7(23.3)$ & $3(10)$ & $10(16.7)$ & \\
\hline Non-smoker $\mathrm{n}(\%)$ & $23(76.7)$ & $27(90)$ & $50(83.3)$ & \\
\hline \multicolumn{5}{|l|}{ Dental visits } \\
\hline Regular n(\%) & $5(16.7 \%)$ & $13(43.3 \%)$ & $18(30 \%)$ & 0.024 \\
\hline Irregular n(\%) & $25(83.3 \%)$ & $17(56.7 \%)$ & $42(70 \%)$ & \\
\hline
\end{tabular}

sd $=$ standard deviation 
Table 3. Comparison of mean clinical parameters in diseased subjects by ethnicity (ANOVA)

\begin{tabular}{lcccc}
\hline Clinical parameters & Malay & Chinese & Indian & Total \\
\hline $\begin{array}{l}\text { Missing teeth } \\
\text { mean (sd) }\end{array}$ & $4.4(3.24)$ & $3.4(2.32)$ & $2.7(2.0)$ & $3.5(2.76)$ \\
$\begin{array}{l}\text { Plaque Index } \\
\text { mean (sd) }\end{array}$ & $1.03(0.39)$ & $1.09(0.40)$ & $1.09(0.37)$ & $1.07(0.36)$ \\
$\begin{array}{l}\text { Gingival Index } \\
\text { mean (sd) }\end{array}$ & $1.16(0.31)$ & $1.32(0.44)$ & $1.23(0.22)$ & $1.24(0.36)$ \\
$\begin{array}{l}\text { Bleeding Index } \\
\text { mean (sd) }\end{array}$ & $68.2(21.5)$ & $76(19.5)$ & $68.7(18.5)$ & $71.0(21.0)$ \\
$\begin{array}{l}\text { PPD } \\
\text { mean (sd) }\end{array}$ & $4.08(0.77)$ & $4.17(0.95)$ & $4.09(2.12)$ & $4.12(0.75)$ \\
$\begin{array}{l}\text { CAL } \\
\text { mean (sd) }\end{array}$ & $5.03(0.99)$ & $5.23(1.26)$ & $5.99(2.19)$ & $5.41(1.15)$ \\
\hline
\end{tabular}

All $p$ values $>0.05$.

sd $=$ standard deviation

Table 4. Prevalence of $A$. actinomycetemcomitans and $P$. intermedia in the subgingival plaque of the three ethnic groups and the total population (Fisher's Exact Test)

\begin{tabular}{|c|c|c|c|c|c|c|c|c|}
\hline & \multicolumn{2}{|c|}{ Malays $(n=20)$} & \multicolumn{2}{|c|}{ Chinese $(n=20)$} & \multicolumn{2}{|c|}{ Indian $(\mathrm{n}=20)$} & \multicolumn{2}{|c|}{ All races $(n=60)$} \\
\hline & $\begin{array}{c}D \\
n(\%)\end{array}$ & $\begin{array}{c}\mathrm{H} \\
\mathrm{n}(\%)\end{array}$ & $\begin{array}{c}D \\
n(\%)\end{array}$ & $\begin{array}{c}\mathrm{H} \\
\mathrm{n}(\%)\end{array}$ & $\begin{array}{c}D \\
n(\%)\end{array}$ & $\begin{array}{c}\mathrm{H} \\
\mathrm{n}(\%)\end{array}$ & $\begin{array}{c}D \\
n(\%)\end{array}$ & $\begin{array}{c}\mathrm{H} \\
\mathrm{n}(\%)\end{array}$ \\
\hline Aa -ve & $9(90)$ & $10(100)$ & $10(100)$ & $10(100)$ & $8(80)$ & $9(90)$ & $27(90)$ & $29(96.7)$ \\
\hline$A a+v e$ & $1(10)$ & - & - & - & $2(20)$ & $1(10)$ & $3(10)$ & 1(3.33) \\
\hline$P i$-ve & $1(10)$ & $1(10)$ & $2(20)$ & $3(30)$ & $1(10)$ & $2(20)$ & $4(40)$ & $6(2)$ \\
\hline$P i+$ ve & $9(90)$ & $9(90)$ & $8(80)$ & $7(70)$ & $9(90)$ & $8(80)$ & $26(86.7)$ & $24(80)$ \\
\hline
\end{tabular}

Aa $=$ A. actinomycetemcomitans

$\mathrm{Pi}=\mathrm{P}$. intermedia

$+\mathrm{ve}=$ present, $-\mathrm{ve}=$ absent

$\mathrm{D}=$ diseased, $\mathrm{H}=$ healthy

subjects, $4(7.4 \%)$ subjects were found to have only A. actinomycetemcomitans present and 50 (92.6\%) subjects had $P$. intermedia present. A. actinomycetemcomitans and $P$. intermedia were detected together in a total of $3(5.56 \%)$ of the 54 subjects harbouring bacteria.

Since the detection level of A. actinomycetemcomitans was very low, it was only possible to relate mean clinical scores in the total subject population and not in the three ethnic groups with the presence or absence of $A$. actinomycetemcomitans (Table 5). Only the mean CAL scores were significantly $(p<0.05)$ higher in the subjects who were $A$. actinomycetemcomitans positive as compared to those who were $A$. actinomycetemcomitans negative which was confirmed with the Mann-Whitney test (2-tailed significance test $)(p<0.05)$.

There was no significant association between mean clinical scores and the presence or absence of $P$. intermedia (Table 5) in the total subject population as well as in the three ethnic groups.

\section{DISCUSSION}

The results of this study demonstrate that prevalence of $A$. actinomycetemcomitans was low and $P$. intermedia high in both the diseased and healthy subjects. There was also no significant association between the presence of $A$. actinomycetemcomitans and $P$. intermedia with ethnicity.

The low prevalence of $A$. actinomycetemcomitans detected in this study is similar to that reported previously by a number of workers who examined subjects based on disease status (10,18-20), although higher detection levels for A. actinomycetemcomitans have also been reported $(8,9,17,21-23)$. In most studies it was found that the prevalence of A. actinomycetemcomitans in subgingival plaque decreases with increasing age and is predominantly associated with younger age groups (24-27). In the present study, subjects were from the $35-65$ years age group. This may explain the low prevalence for A. actinomycetemcomitans in both the diseased and healthy subjects as it did not include younger age groups. 
Table 5. Mean clinical scores related to the presence or absence of $A$. actinomycetemcomitans and $P$. intermedia in the total study population (One-way ANOVA)

\begin{tabular}{lcccc}
\hline & $\begin{array}{c}\text { Aa }+v e(\mathrm{n}=56) \\
\text { Mean }( \pm \mathrm{sd})\end{array}$ & $\begin{array}{c}\text { Aa }-v e(\mathrm{n}=4) \\
\text { Mean }( \pm \mathrm{sd})\end{array}$ & $\begin{array}{c}P i+v e(\mathrm{n}=50) \\
\text { Mean }( \pm \mathrm{sd})\end{array}$ & $\begin{array}{c}P i-v e(\mathrm{n}=10) \\
\text { Mean }( \pm \mathrm{sd})\end{array}$ \\
\hline Missing teeth & $4.00( \pm 4.08)$ & $2.91( \pm 2.54)$ & $3.22( \pm 2.67)$ & $1.80( \pm 2.2)$ \\
Plaque Index & $0.91( \pm 0.47)$ & $0.73( \pm 0.45)$ & $0.75( \pm 0.47)$ & $0.69( \pm 0.38)$ \\
Gingivitis index & $1.04( \pm 0.66)$ & $0.73( \pm 0.58)$ & $0.76( \pm 0.57)$ & $0.67( \pm 0.67)$ \\
Bleeding index & $58.85( \pm 37.28)$ & $42.27( \pm 32.33)$ & $44.97( \pm 32.65)$ & $35.42( \pm 32.84)$ \\
ProbingPocket depth & $4.19( \pm 1.47)$ & $3.03( \pm 1.13)$ & $3.12( \pm 1.18)$ & $3.05( \pm 1.21)$ \\
Clinical attachment level & $5.90( \pm 2.52)^{*}$ & $3.63( \pm 1.73)$ & $3.79( \pm 1.86)$ & $3.69( \pm 1.94)$ \\
\hline
\end{tabular}

\section{${ }^{*} p<0.05$}

sd $=$ standard deviation

$A a=A$. actinomycetemcomitans

$P i=P$. intermedia

$+\mathrm{ve}=$ present,$-\mathrm{ve}=\mathrm{absent}$

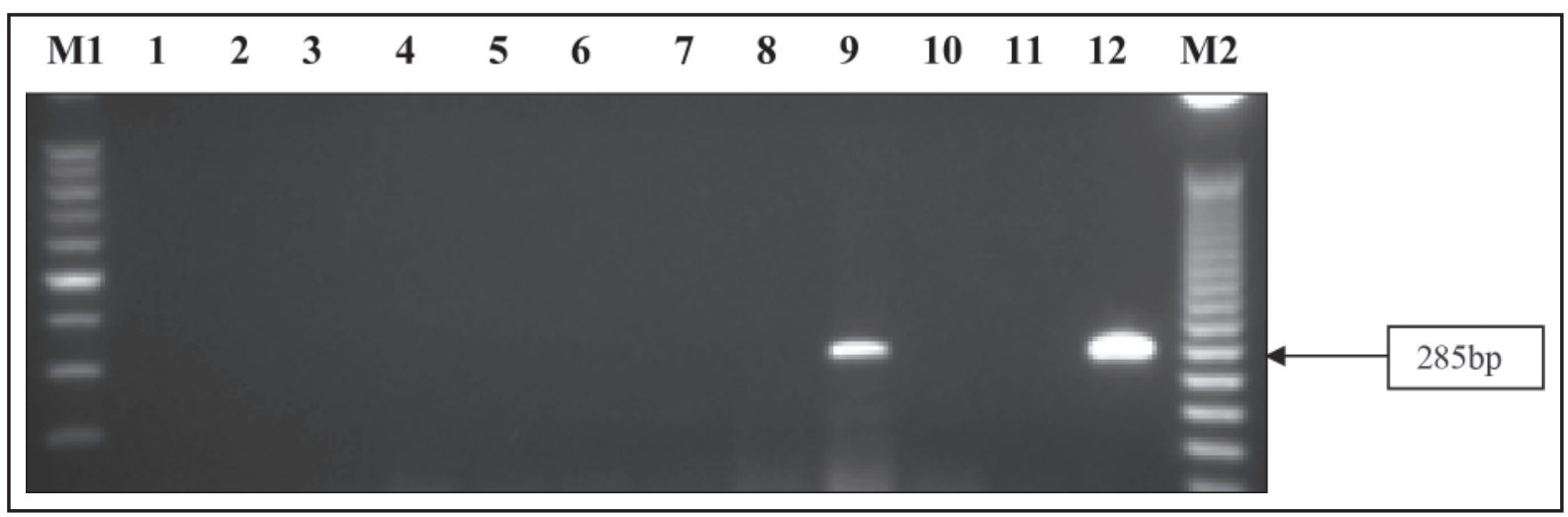

Figure 1. Identification of A.actinomycetemcomitans in the subgingival plaque samples of Malay subjects with Advanced Chronic Periodontitis.

M1 denotes the 100bp molecular size marker and M2 denotes the $50 \mathrm{bp}$ molecular size marker. Lanes 1 to 10 are samples of diseased Malay subjects. Lane 11 is the negative control and Lane 12 is the positive control. Subject 9 was positive for A.actinomycetemcomitans.

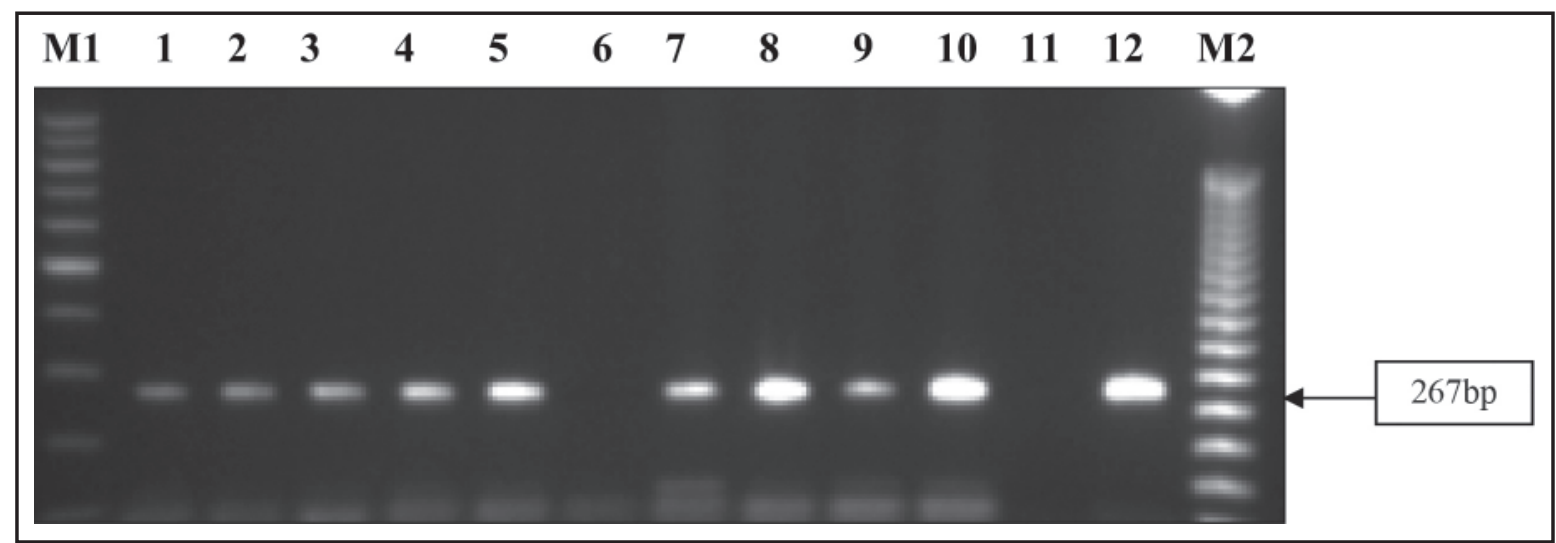

Figure 2. Identification of P.intermedia in the subgingival plaque samples of Advanced Chronic Periodontitis Malay subjects. M1 denotes the $100 \mathrm{bp}$ molecular size marker and M2 denotes the $50 \mathrm{bp}$ molecular size marker. Lanes 1 to 10 are samples of diseased Malay subjects. Lane 11 is the negative control and Lane 12 is the positive control. Nine out of ten subjects were positive for $P$. intermedia.

Studies comparing periodontitis patients in Spain and Netherlands (28) observed that A. actinomycetemcomitans was significantly more prevalent in the Dutch patients (25\% versus $35 \%$ ). van Winkelhoff et al (29) observed that this may be related to the significant difference in medical use of antibiotics in the two countries. Netherlands is the most restrictive country in Europe while Spain is among the countries that use the highest number of antibiotics per inhabitant (30). Differences in medical use of 
antibiotics among Malaysian subjects as compared to countries where higher detection levels for $A$. actinomycetemcomitans have been reported may also exist.

In this study population, A. actinomycetemcomitans was not identified in Malaysian Chinese diseased and healthy groups. This finding is in agreement with $\mathrm{Cao}$ et al (31), where A. actinomycetemcomitans was not detected in visiting Chinese male students in USA who had periodontitis. The findings are however in contrast to the high detection levels of $A$. actinomycetemcomitans in the normal flora of young Chinese subjects in China (9) and Singaporean Chinese subjects (17). The difference could probably be explained by the small number of Chinese subjects used in the present study (20 subjects) and in the study by Cao's group (10 subjects) (31) as compared to the studies done in Chinese subjects in China (9) as well as in Singapore (17) where their sample sizes were 185 and 92 subjects respectively.

The high prevalence for $P$. intermedia in this study is also consistent with many other studies $(18,19,23,32,33)$. The results of this study also confers with the finding by Teanpaisan et al (34) who reported that the incidence of $P$. intermedia was no greater in disease than in health. However, reports of a much lower prevalence for $P$. intermedia have also been published $(21,25)$.

In this study, A. actinomycetemcomitans and $P$. intermedia were found together in only $5.56 \%$ of the total infected subjects (healthy and diseased). This is consistent with the results by Hamlet and colleagues (25) where co-infection by $A$. actinomycetemcomitans and $P$. intermedia were found in only $4 \%$ of the infected subjects. The existence of antagonistic interactions whereby one microorganism (P. intermedia) can inhibit the second microorganism (A. actinomycetemcomitans) may have given rise to there being a protective oral flora $(35,36)$.

The effect of mixed microbial infections that may enhance pathogenicity of individual species also needs to be considered. Slots \& Genco (37) have stated that pure cultures of Bacteroides like P. intermedia generally do not cause an infectious lesion but combinations of $P$. intermedia and $P$. gingivalis may have a synergistic effect and cause such a lesion. Socransky et al (3) have also stated that $P$. intermedia, which is in the orange complex of the model of bacterial complexes of the dental biofilm associated with periodontal disease, acts as a bridge between the early colonizers and the red complex species $(P$. gingivalis, T. denticola and T. forsythus). Therefore in this study, there is a possibility that the diseased patients may have had an increased presence of $P$. gingivalis, which may not have been present in the healthy subjects, and this synergistic combination may be the cause for disease.
This study demonstrated that A. actinomycetemcomitans had a significant association with CAL and not with other clinical parameters. $P$. intermedia however was not associated with any of the clinical parameters. Other than the association that A. actinomycetemcomitans had on CAL, there was insufficient evidence to show similar findings that were seen in earlier studies $(3,38)$ where they found that elevated levels of species like A. actinomycetemcomitans, $P$. intermedia, $P$. gingivalis, $T$. forsythensis and T. denticola were correlated with increasing PPD and CAL. In contrast, studies by Cullinan et al (35) and Timmerman et al (8) showed that $A$. actinomycetemcomitans and $P$. intermedia had no significant effects on PPD and CAL.

\section{CONCLUSION}

In this study none of the pathogens were associated with the race and periodontal disease status of the subjects and only $A$. actinomycetemcomitans had a significant association with CAL. The findings in this study have to be taken with caution due to the small sample population. We recommend that a future study be conducted which involves a larger randomly selected sample population. This will reflect the true prevalence of these bacteria in the Malaysian population at large.

\section{ACKNOWLEDGEMENTS}

This study was supported by Vote F 0130 /2003C, University of Malaya. The authors would like to thank Dr Luay Thanoon Younis for his help in examining patients and Dr Khamiza Zainol Abidin for her help in subject selection for this study.

\section{REFERENCES}

1. Socransky SS, Haffajee AD. Dental biofilms: difficult therapeutic targets. Periodontol 2000 2002; 28: 12-55.

2. Kumar PS, Leys EJ, Bryk JM, Martinez FJ, Moeschberger ML, Griffen AL. Changes in periodontal health status are associated bacterial community shifts as assessed by quantitative $16 \mathrm{~S}$ cloning and sequencing. J Clin Microbiol 2006; 44: 3665-73.

3. Socransky SS, Haffajee AD, Cugini MA, Smith C, Kent RL. Microbial complexes in subgingival plaque. J Clin Periodontol 1998; 25: 134-44. 
4. Socransky SS, Haffajee AD. The bacterial etiology of destructive periodontal disease: Current concepts. J Periodontol 1992; 63: 322- 31.

5. Wolff L, Dahlen G, Aeppli D. Bacteria as risk markers for periodontitis. J Periodontol 1994; 64: 498-510.

6. Schenkein HA, Burmeister JA, Koertge TE, Brooks CN, Best AM, Moore LVH, Moore WEC. The influence of race and gender on periodontal microflora. J Periodontol 1993; 64: 292-6.

7. McNabb H, Mombelli A, Gmur R, Mathey-Dinc S,Lang NP. Periodontal pathogens in the shallow pockets of immigrants from developing countries. Oral Microbiol Immunol 1992; 7(5): 267-72.

8. Timmerman MF, Van der Weijden GA, Armand S, Abbas F, Winkel EG, Van Winkelhoff AJ, Van der Velden U. Untreated periodontal disease in Indonesian adolescents. Clinical \& microbiological baseline data. J Clin Periodontol 1998; 25: 215-24.

9. Mombelli A, Gmur R, Lang NP, Corbet E, Frey J. Actinobacillus actinomycetemcomitans in Chinese adults. Serotype distribution and analysis of the leukotoxin gene promoter locus. J Clin Periodontol 1999; 26(8): 505-10.

10. Yano-Higuchi K, Takamatsu N, He T, Umeda M, Ishikawa I. Prevalence of $B$. forsythus, $P$. gingivalis and $A$. actinomycetemcomitans in subgingival microflora of Japanese patients with adult and rapidly progressive periodontitis. J Clin Periodontol 2000; 27: 597-602.

11. Taiyeb Ali T. Epidemiological periodontal research and investigations in Malaysia. In Progress of Periodontal Research and Practice in Asian Pacific Countries, Chap 3, Bartold PM, Ishikawa I, Sirirat M, eds, 2000 Asian Pacific Society of Periodontology, 24-34.

12. Silness J, Loe H. Periodontal disease in pregnancy. II. Correlation between oral hygiene and periodontal condition. Acta Odont Scand 1964; 22: 121-35.

13. Loe H, Silness J. Periodontal disease in pregnancy. Prevalence and severity. Acta Odontol Scand 1963; 21: 533-51.

14. Muhlemann HR, Son S. Gingival sulcus bleeding - a leading symptom in initial gingivitis. Helv Odontol Acta 1971; 15(2): 107-11.
15. Premraj T, Kato N, Fukui K, Kato H, Watanabe K. Use of PCR and sodium dodecyl SulphatePolyacrylamide gel electrophoresis techniques for differentiation of $P$. intermedia Sensu stricto and P. nigrescens. J Clin Microbiol 1999; 37(4):105764.

16. Tonjum T, Haas R. Identification of $A$. actinomycetemcomitans by leukotoxin genespecific hybridization and PCR assays. J Clin Microbiol 1993; 31(7): 1856-9.

17. Tan KS, Woo CH, Ong G, Song KP. Prevalence of A. actinomycetemcomitans in an ethnic adult Chinese population. J Clin Periodontol 2001; 28: 886-90.

18. Darby IB, Hodge PJ, Riggio MP, Kinane DF. Microbial comparison of smoker and non-smoker adult and EOP patients by PCR. J Clin Periodontol 2000; 27: 417-24.

19. Preus HR, Anerud A, Boysen H, Dunford RG, Zambon JJ, Loe H. The natural history of periodontal disease. The correlation of selected microbiological parameters with disease severity in Sri Lankan tea workers. J Clin Periodontol 1995; 22: 674-8.

20. Mandell RL, Socransky SS. A selective medium for A. actinomycetemcomitans and the incidence of the organism in juvenile periodontosis. $J$ Periodontol 1981; 52(10): 593-8.

21. Chandrapho N., Jiraviboon D., Cheucharoenvasuchai $\mathrm{N}$, Prajaneh $\mathrm{S}$. Relationship between $P$. gingivalis, $A$. actinomycetemcomitans, $P$. intermedia and $F$. nucleatum and periodontal status in patients treated at Faculty of Dentistry, Khon Kaen University. Khon Kaen Dent J 2000; 3(1): 67-71.

22. Riggio MP, Macfarlane TW, Mackenzie D, Lennon A, Smith AJ, Kinane DF. Comparison of PCR and culture methods for detection of A. actinomycetemcomitans and $P$. gingivalis in subgingival plaque samples. J Perio Res 1996; 31(7): 496-501.

23. van Winkelhoff AJ, Loos BG, Van der Reijden WA, van der Velden U. P. gingivalis, B. forsythus and other putative periopathogens in subjects with and without periodontal destruction. J Clin Periodontol 2002; 29: 1023-8.

24. Slots J, Ram TE, Feik D, Taveras HD, Gillespie GM. Subgingival microflora of advanced periodontitis in the Dominican Republic. J Periodontol 1991; 62(9): 543-7. 
25. Hamlet SM, Cullinan MP, Westerman B, Lindeman M, Bird PS, Palmer J, Seymour GJ. Distribution of A. actinomycetemcomitans, $P$. gingivalis and $P$. intermedia in an Australian population. J Clin Periodontol 2001; 28: 1163-71.

26. Haubek D, Ennibi OK, Poulsen K, Vaeth M, Poulsen S, Kilian M. Risk of aggressive periodontitis in carriers of the JP2 clone of Aggregatibacter (Actinobacillus) actinomycetemcomitans in Morocco: a longitudinal cohort study. Lancet 2008; 19: 237-42.

27. Van der Velden, Abbas F, Armand S, Loos BG, Timmerman MF, van der Weijden GA, van Winkelhoff AJ, Winkel EG. Java project on natural diseases. The natural development of periodontitis: risk factors, risk predictors \& risk determinants. J Clin Periodontol 2006; 33: 540-8.

28. Sanz M, van Winkelhoff AJ, Herrera D, lemijnKippuw N, Simon R, Winkel E. Differences in the composition of the subgingival microbiota of two periodontitis populations of different geographical origin. A comparison between Spain and the Netherlands. Eur J Oral Sci 2000; 108: 383-92.

29. van Winkelhoff AJ, Herrera D, Oteo A, Sanz M. Antimicrobial profiles of periodontal pathogens isolated from periodontitis patients in the Netherlands and Spain. J Clin Periodontol 2005; 32: 893-8.

30. Rylev M, Kilian M. Prevalence and distribution of principle periodontal pathogens worldwide. J Clin Periodontol 2008; 35: 346-61.

31. Cao CF, Aeppli DM, Liljemark WF, Blomquist CG, Bandt CL, Wolff LF. Comparison of plaque microflora between Chinese and Caucasian population groups. J Clin Periodontol 1990; 17: $115-8$.
32. Papapanou P.N, Baelum V, Luan WM, Madianos PN, Chen X, Fejerskov O, Dahlen G. Subgingival microbiota in adult Chinese: prevalence and relation to periodontal disease progression. J Periodontol 1997; 68: 651-66.

33. Dahlen G. Role of suspected periodontopathogens in microbiological monitoring of periodontitis. Adv Dent Res 1993; 7(2): 163-74.

34. Teanpaisan R, Douglas CWI, Eley AR, Walsh TF. Clonality of Porphyromonas gingivalis, Prevotella intermedia and Prevotella nigrescens isolated from periodontally diseased and healthy sites. J Periodontol Res 1996; 31: 423-32.

35. Cullinan MP, Hamlet SM, Westerman B, Palmer JE, Faddy MJ, Geymour GJ. Acquisition and loss of $P$. gingivalis, $A$. actinomycetemcomitans and $P$. intermedia over a 5-year period: effect of a triclosan/co-polymer dentifrice. J Clin Periodontol 2003; 30: 532-41.

36. Maiden MF, Carman RJ, Curtis MA, Gillet IR, Griffiths GS, Strene JA, Wilton JM, Johnson NW. Detection of high risk groups and individuals for periodontal disease: lab markers based on microbiological analysis of subgingival plaque. J Clin Periodontol 1990; 17(1): 1-13.

37. Slots J, Genco RJ. Black-pigmented Bacteroides species, Capnocytophaga species, and A. actinomycetemcomitans in Human Periodontal disease: Virulence factors in colonization, survival and tissue destruction. J Dent Res 1984; 63(3): 41221.

38. Grossi SG, Zambon JJ, Ho AW, Koch G, Dunford RG, Machtei EE, Norderyd OM, Genco RJ. Assessment of risk for periodontal disease I. Risk indicators for attachment loss. J Periodontol 1994; 65(3): 260-7. 